OPEN ACCESS

Edited by: Juliana Leme,

University of São Paulo, Brazil

Reviewed by: B. Runnegar, University of California, Los Angeles, United States Shuhai Xiao, Virginia Tech, United States

*Correspondence: Daniel Pérez-Pinedo dperezpinedo@mun.ca

Specialty section: This article was submitted to Paleontology,

a section of the journal

Frontiers in Earth Science

Received: 29 September 2021 Accepted: 20 December 2021 Published: 20 January 2022

Citation:

Pérez-Pinedo D, McKean C, Taylor R, Nicholls $R$ and Mcllroy D (2022) Charniodiscus and Arborea Are Separate Genera Within the Arboreomorpha: Using the Holotype of C. concentricus to Resolve a Taphonomic/Taxonomic Tangle. Front. Earth Sci. 9:785929. doi: 10.3389/feart.2021.785929

\section{Charniodiscus and Arborea Are Separate Genera Within the Arboreomorpha: Using the Holotype of C. concentricus to Resolve a Taphonomic/Taxonomic Tangle}

\author{
Daniel Pérez-Pinedo ${ }^{1 *}$, Christopher McKean ${ }^{1}$, Rod Taylor ${ }^{1}$, Robert Nicholls ${ }^{2}$ and \\ Duncan Mcllroy ${ }^{1}$
}

${ }^{1}$ Department of Earth Sciences, Memorial University of Newfoundland, St. John's, NL, Canada, ${ }^{2}$ Paleocreations, Bristol, United Kingdom

Charniodiscus is one of the most iconic and first described of the Ediacaran frondose taxa. Since the diagnosis of the holotype of $C$. concentricus in 1958, the scarcity and poor preservation of unequivocal specimens has resulted in genus-level taxonomic uncertainty. Since the recent reinterpretation of $C$. concentricus as a multifoliate frond, other Charniodiscus species - all of which are bifoliate-have been left in taxonomic limbo, with most authors comparing them to the clade Arboreomorpha and also the Rangeomorpha. Reconsideration of the taphonomy of the holotype of $C$. concentricus has revealed that the frond is bifoliate as first described, and also that the frondose portion was broadly conical rather than planar as previously inferred. The conical frond of Charniodiscus is thus morphologically quite different from all other frondose taxa within the Arboreomorpha. Our emendation of the generic diagnosis of Charniodiscus to encompass bifoliate arboreomorphs with conical fronds without a backing sheet distinguishes Charniodiscus concentricus and $C$. procerus from more planar leaf-like arboreomorphs such as Arborea arborea, A. longa and A. spinosa, all of which have a distinctive backing sheet. Additionally, we find no evidence of rangeomorph-type fractal branching in Charniodiscus.

Keywords: Charniodiscus, Arborea, holotype, taxonomy, taphonomy, Ediacaran, Avalon

\section{INTRODUCTION}

Charniodiscus Ford, 1958 was one of the first described fossils from the Ediacaran and is one of the most iconic-and most often illustrated-of the frondose Ediacaran taxa. The type species of the genus, Charniodiscus concentricus, was described from Charnwood Forest, UK (Ford, 1958) (Figure 1). C. concentricus was originally described as an organ taxon i.e., the disc part of Charnia masoni (Ford, 1958), but subsequently as a bifoliate frond with a stem and a basal disc (Ford, 1963). However, more recently consensus has shifted towards it being a multifoliate frond (Dzik, 2002; Brasier and Antcliffe, 2009; Liu et al., 2017). The genus has been compared to both the Rangeomorpha (Brasier et al., 2012) and the Arboreomorpha (Erwin et al., 2011) with current consensus being that most, if not all, Charniodiscus species are arboreomorphs (e.g., Laflamme et al., 2018; Dunn et al., 2019). The commonly accepted species of Charniodiscus include C. concentricus 


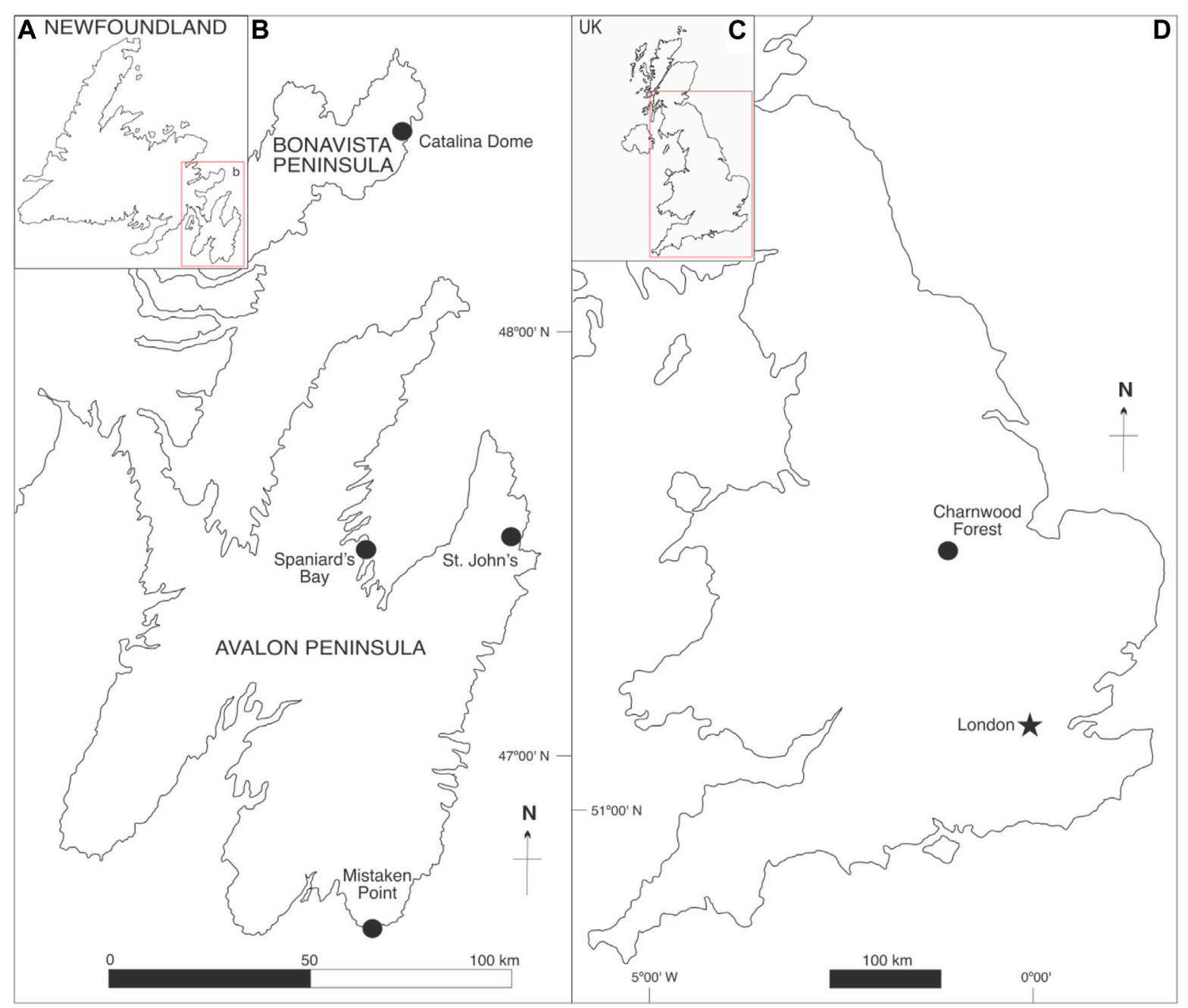

FIGURE 1 | Map of some of the most relevant Avalonian fossil assemblages (black circles). (A) General map of Newfoundland, Atlantic Canada. (B) Detail of the Avalon and Bonavista Peninsulas. (C) General map of the United Kingdom. (D) Detail of England.

Ford 1958; C. longus Glaessner and Wade, 1966; C. yorgensis Borchvardt and Nessov, 1999; C. procerus Laflamme et al., 2004; and C. spinosus Laflamme et al., 2004 (Figure 2).

The taxonomy of Charniodiscus remains incompletely resolved in large part due to the complex preservation of the type species of Charniodiscus (cf. Brasier and Antcliffe, 2009; Brasier et al., 2012; Figure 3). While some species previously described as Charniodiscus are currently considered to be arboreomorphs (e.g., Arborea) (Laflamme et al., 2018; Dunn et al., 2019), those works have not addressed the morphology and taphonomy of the type species of the genus directly. Charniodiscus has been reported to have a worldwide distribution from sites in: Charnwood Forest, UK (e.g., Ford, 1958; Ford, 1962; Ford, 1963; Wilby et al., 2011); South Australia (e.g., Glaessner and Daily, 1959; Glaessner and Wade, 1966; Jenkins and Gehling, 1978; Gehling, 1991; Jenkins, 1992-though most of these occurrences are now considered to be Arborea); the White Sea region of Russia (Fedonkin, 1985;
Ivantsov, 2016); north-western Canada (Narbonne and Hofmann, 1987); and Newfoundland, Canada (e.g., Jenkins, 1992; Seilacher, 1992; Hofmann et al., 2008). Charniodiscus is thus a cosmopolitan taxon whose taxonomy and relationship to the somewhat similar Arborea is of global relevance. This study aims to improve palaeobiological understanding of the common species within Charniodiscus by reconsideration of the taphonomy and morphology of the type material from Charnwood Forest, UK, and the abundant Charniodiscus of the Newfoundland Ediacaran biotas of the Avalon and Bonavista peninsulas.

\section{Preservation in the Avalon Assemblage}

During periods of low sedimentation rates or hiatus, Ediacaran seafloors were commonly colonized by microbial matgrounds-likely mainly photosynthetic in shallow marine settings and chemosynthetic or chemoheterotrophic in deep marine settings. Matgrounds in waters of all depths in the 


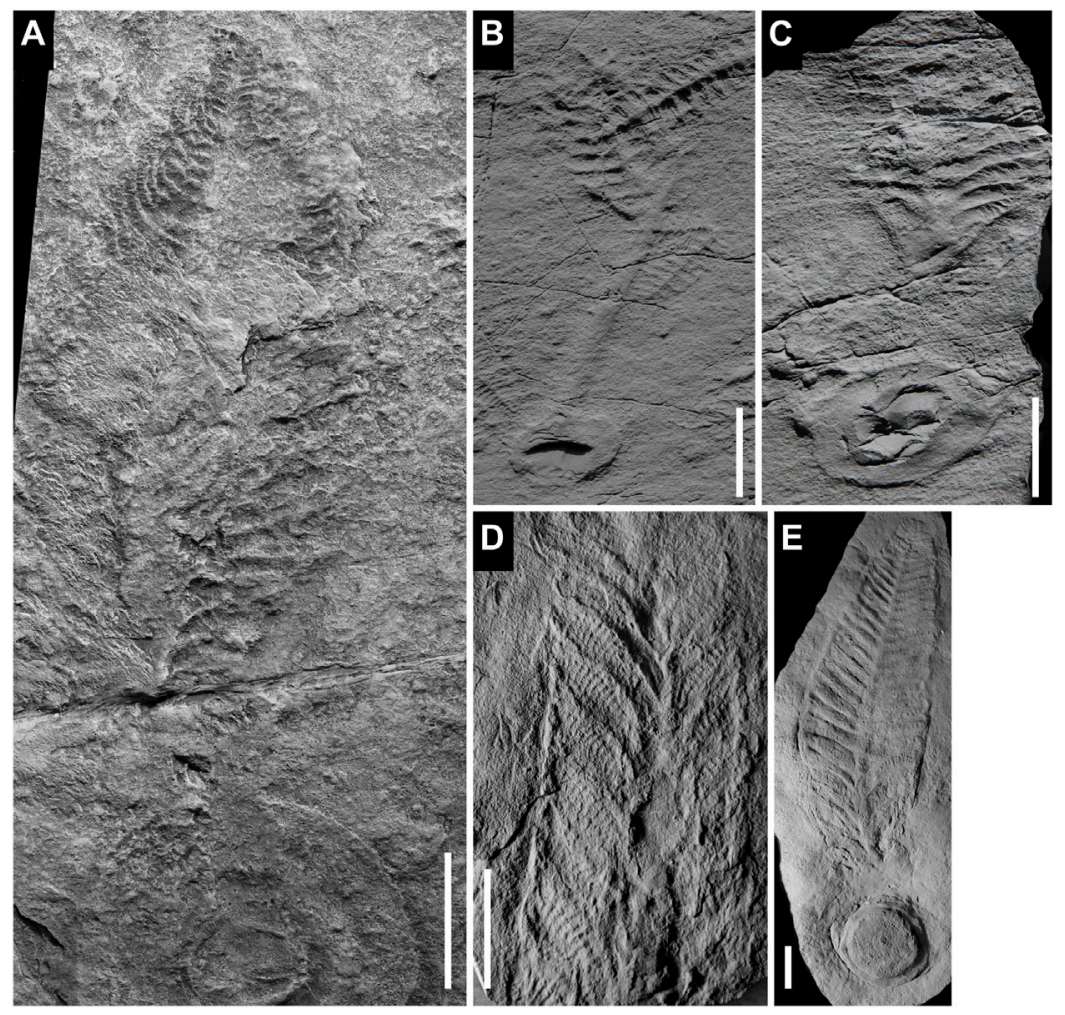

FIGURE 2 | Casts of relevant Charniodiscus species. (A) C. concentricus holotype (LEIUG 2383) from Charnwood Forest, UK. (B,C) C. procerus and C. spinosus respectively from the upper part of the Mistaken Point Formation ("E'"-surface) at Mistaken Point, Newfoundland. Jesmonite cast of field specimens. (D,E) C. longus cast (SAM P13777) and C. arboreus (Arborea) cast (OUMNH AW.00043/p) respectively from Ediacara, South Australia. Scale bars 3 cm. Not retrodeformed.

Ediacaran were exceptionally well developed and well preserved, owing to the rarity of motile macrobionts (e.g., Liu et al., 2010), macrobioturbation (McIlroy and Logan, 1999), and ecosystem services like scavenging and grazing (Herringshaw et al., 2017); this would also have led to the persistence of abundant seafloor necromass (Liu et al., 2011; McIlroy et al., 2021). The importance of matgrounds for soft bodied preservation of Ediacaran organisms has been extensively explored based around the death mask model of mouldic preservation proposed by Gehling (1999) and extended to encompass aspects of early diagenetic mineralization (Mapstone and McIlroy, 2006; Liu, 2016) and preservation as original carbonaceous compressions (e.g., Steiner and Reitner, 2001; Xiao et al., 2002). The role of sedimentological parameters as they interface with taphonomic processes in taphonomy is pivotal but remains under-studied (Kenchington and Wilby, 2014).

The Avalon Assemblage (Waggoner, 2003) is the oldest of the Ediacaran assemblages. The earliest known Ediacaran fossils are from deep marine volcaniclastic settings of the Avalon Terrane in Newfoundland spanning at least the interval ca. 574-564 Ma (Matthews et al., 2021) and Charnwood Forest, UK, (Noble et al., 2015). These successions form part of the peri-Gondwanan Avalonian volcanic arc system (Murphy et al., 2004; McIlroy and Horák, 2006; Wen et al., 2020) and predominantly consist of turbidites and laterally extensive tuffites (McIlroy et al., 1998; Wood et al., 2003; Matthews et al., 2021). The soft bodied Ediacaran fossils are typically preserved as impressions on top of volcaniclastic siltstones, particularly where they are overlain by tuffites (Narbonne, 2005; Liu et al., 2015; Matthews et al., 2021). Positive epireliefs are the most common mode of preservation for stems and some basal discs of frondose organisms, which implies that they maintained their integrity long enough for lithification of the overlying tuff. Negative epirelief moulds are typically associated with the less resistant frondose portions of quasiinfaunal reclining organisms (permanently affixed to the seafloor), produced by smothering of matgrounds by dead/ felled erect or recumbent (parallel and elevated above the seafloor in a windsock-like manner) organisms (McIlroy et al., 2009) or by sediment-displacing growth of quasi-infaunal reclining organisms (McIlroy et al., 2020; Taylor et al., 2021; McIlroy et al., 2021) (Figure 4). Soft bodied Ediacaran taphonomic style is influenced by a combination of: 1) differential decomposition rates of labile vs relatively refractory body tissues; 2) the influence of currents and related sedimentary processes; 3) body posture in life; and 4) the nature of seafloor microbial matgrounds associated with the organism in life (e.g., Wade, 1968; Gehling, 1999; Narbonne, 2005; McIlroy et al., 2020, McIlroy et al., 2021). 


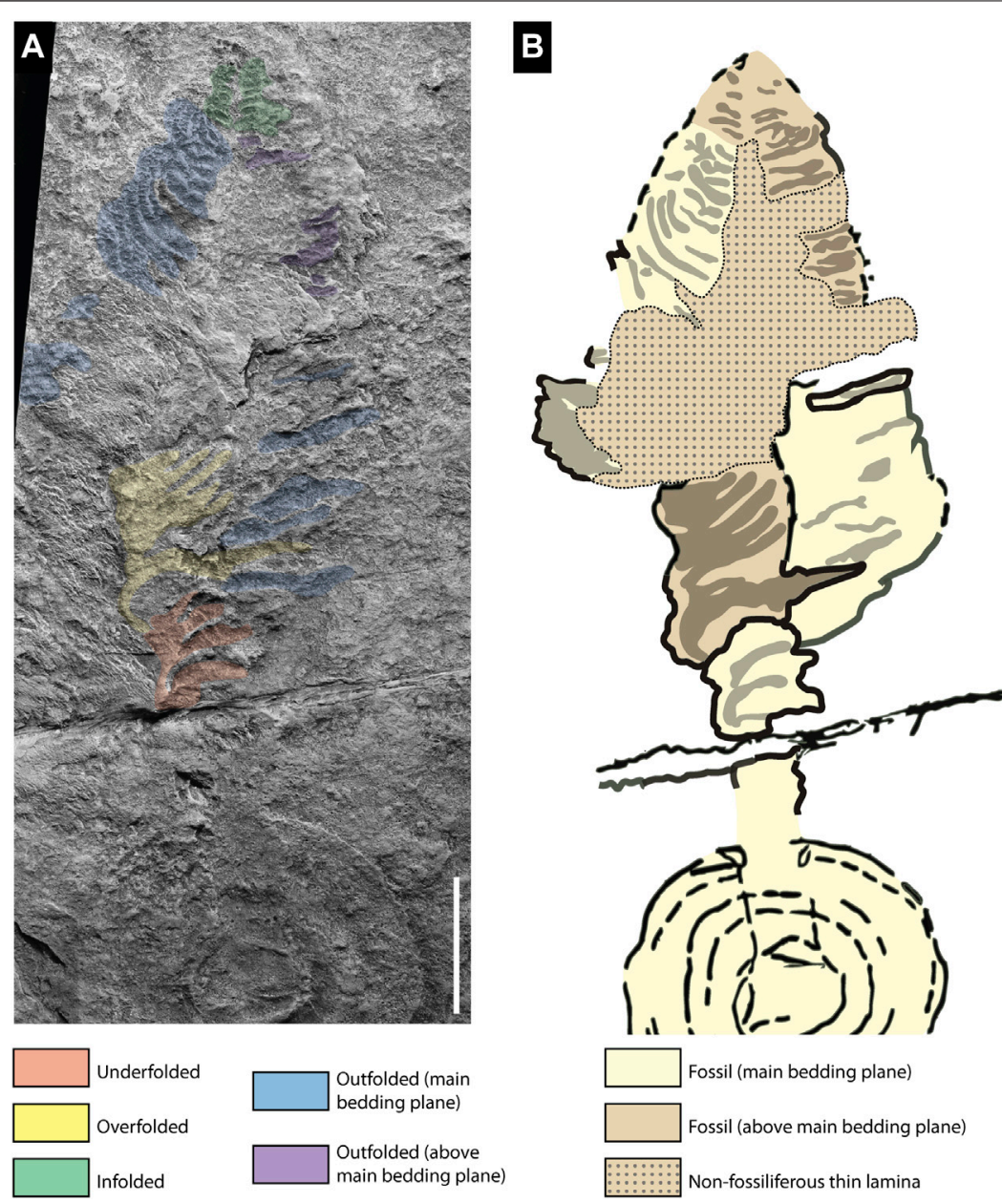

FIGURE 3 | Preservation of the holotype of C. concentricus (LEIUG 2383) from Charnwood Forest, UK. (A) Differential branch folding; underfolded (orange), overfolded (yellow), outfolded (blue and purple) and infolded (green). (B) Interpretive drawing of the fossil showing features preserved in different bedding planes; main bedding plane (yellow), above bedding plane (brown), and non-fossiliferous sediment (dotted brown pattern). Scale bar $3 \mathrm{~cm}$. Not retrodeformed.

Aside from the holotype of the type species of Charniodiscus (Charnwood Forest, UK) most of the specimens of the genus are known from Newfoundland and have been described from either Mistaken Point (Laflamme et al., 2004) or the Catalina Dome (Hofmann et al., 2008). In both locations, the top surfaces of the basal discs and stems-as well as the junction between them-are commonly preserved as positive epireliefs whereas the frondose portions commonly lie beneath the ambient bedding plane. This suggests preservation by matground smothering (McIlroy et al., 2009; Figure 4) with sharp ridges occurring due to post-mortem sediment infiltration between frondose elements. In the younger Charnian assemblage of the UK the Ediacaran biotas are typically preserved as very low negative and positive epirelief impressions on fine-grained surfaces under a thin tuffaceous layer (Brasier and Antcliffe, 2009; Wilby et al., 2011), like the Conception-type preservation (Narbonne, 2005). This assemblage shares some genera with Newfoundland, but like Newfoundland also includes several endemic taxa.

\section{Previous Taphonomic/Morphological Consideration of the Charniodiscus concentricus Holotype}

The Arboreomorpha (Erwin et al., 2011; cf. the Frondomorpha of Grazhdankin, 2014) encompasses numerous frondose species that lack the fractal-like branching of the Rangeomorpha (Narbonne, 2004; Brasier and Antcliffe, 2004, Brasier and Antcliffe, 2009). Arboreomorphs are characterized by arboreomorph branching architecture in which rows of primary branches project from the central stalk extending to an outer rim and may have transverse structures called second order branches (Laflamme and Narbonne, 2008; Erwin et al., 2011). The clade encompasses two genera, Charniodiscus and Arborea, whose taxonomic relationship has hitherto been confused. Some authors have considered Arborea to be a junior synonym of Charniodiscus on the basis of similar gross morphology (Glaessner and Daily, 1959; Jenkins and Gehling, 1978). The Newfoundland Charniodiscus species (C. spinosus, C. 


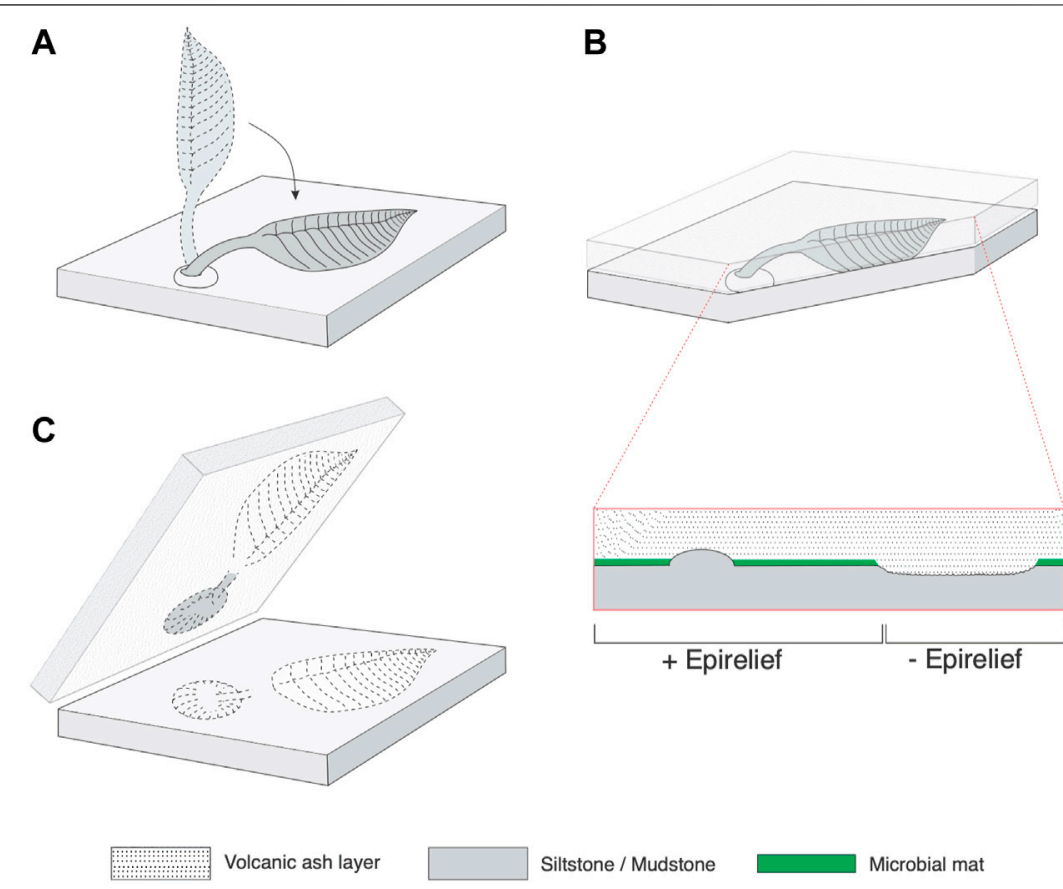

FIGURE 4 | Preservation style observed in Ediacaran organisms in Avalonia. (A): Felling of an undetermined erect stemmed frond. (B): Transversal cut of the felled frond preserved between the underlying volcaniclastic siltstone and the overlying tuffite; close-up shows features preserved in positive and negative reliefs and smothered matground. (C): Resulting reliefs in the underlying volcaniclastic siltstone and their counterparts in the tuffaceous layer.

procerus and $C$. arboreus) have been attributed to the Arboreomorpha, but not closely related to the type species of Charniodiscus (e.g., Laflamme et al., 2004; Hofmann et al., 2008; Liu et al., 2015), however, there has been no attempt to formally move these taxa out of Charniodiscus. These taxonomic interpretations are further confused by differing opinions on the morphology and taphonomy of the holotype of Charniodiscus concentricus (Dzik, 2002; Brasier and Antcliffe, 2009). It has been suggested that $C$. concentricus is a multifoliate rangeomorph rather than an arboreomorph, albeit without observable rangeomorph branching (undivided and furled morphology cf. Brasier and Antcliffe, 2009; Brasier et al., 2012), which we do not consider to be objectively testable.

Charniodiscus concentricus is a soft-bodied unipolar, lanceolate to ovate frondose organism consisting of a segmented frond and a cylindrical stem, which is associated with a basal disc (e.g., Brasier and Antcliffe, 2009; Figure 2A). The term holdfast is not used herein as it implies a biomechanical function that cannot be unequivocally demonstrated. The frond presents 30 to 50 primary branches attached to both sides of the stem in either alternating or opposing arrangements. The primary branches of $C$. concentricus have secondary order bar-like transverse structures (e.g., Laflamme et al., 2004) (Figure 3A). There is also a pronounced curvature to the primary branches, and a notable decrease in branch width and length towards the frond apex (which has been considered a species-level difference between C. concentricus and Arborea (Jenkins and Gehling, 1978; Laflamme et al., 2004). The widely accepted multifoliate nature of C. concentricus (Dzik, 2002; Brasier and Antcliffe, 2009,
Figure 12) is currently considered to be one of the fundamental differences between Charniodiscus and Arborea spp. (Liu et al., 2017; Dunn et al., 2019).

The holotype of $C$. concentricus combines both positive and negative epirelief impressions and includes some preservation on the tuffaceous siltstone that is at a level slightly above the main microbially-dominated bedding plane associated with the basal disc (Figure 3B). Both the basal disc and the stem are preserved in low positive epirelief, although the latter may be a partially collapsed remnant of what was originally a cylindrical structure. The central and distal-most sections of the frond are preserved in negative relief but at a level slightly above the main bedding plane, while the proximal arcuate subparallel primary branches are in negative epirelief on the same surface as the basal disc and stem (Brasier and Antcliffe, 2009; Figure 3B).

\section{Historical Reasoning for A Multifoliate Charniodiscus concentricus}

Explanation of the biostratinomy of the Charniodiscus type species as a bifoliate frond in which the bottom-left part of the frond was overfolded (Jenkins and Gehling, 1978, Figures $4 \mathrm{X}, \mathrm{Y}$ ) has more recently been superseded by a multifoliate model (Dzik, 2002; Brasier and Antcliffe, 2009, Figure 12). The multifoliate model invokes the presence of at least three foliate sheets of primary branches resembling rangeomorph branching (Brasier and Antcliffe, 2009; Brasier et al., 2012).

The acceptance of the multifoliate nature of the holotype of the type species of Charniodiscus resulted in taxonomic 


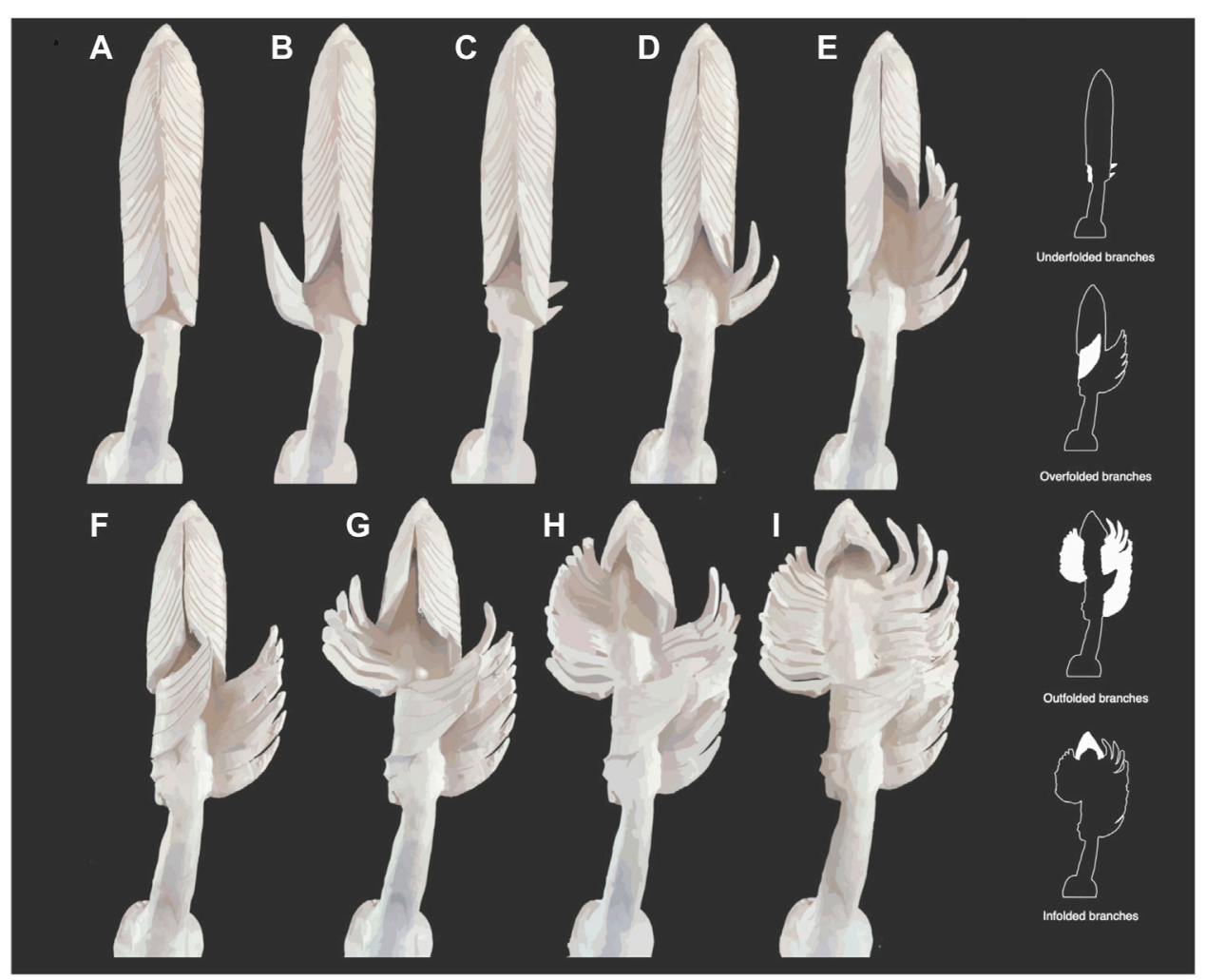

FIGURE 5 | Taphonomic stop-motion model of the holotype of C. concentricus showing different branch folding. (A-C) underfolding of proximal-most branches. (A-I) infolding of distal-most branches. (D-I) outfolding of bottom-right and central branches. (F-I) overfolding of bottom-left branches.

inconsistencies regarding the other bifoliate species of the genus (Laflamme et al., 2018). Moreover, since there is no evidence to support fractal branching architecture, assignment of the genus to the Rangeomorpha (undivided rangeomorph branching of Brasier et al., 2012) is unsupported. The Newfoundland species of Charniodiscus have remained within the genus, despite the inferred multifoliate nature of the type species (Laflamme and Narbonne, 2008), but have also been considered to be separate from Arborea based on branching criteria of Brasier et al. (2012). The need to unravel this taphonomic, and taxonomic, tangle has been mentioned in the literature by numerous authors (e.g., Brasier and Antcliffe, 2009; Liu et al., 2015; Laflamme et al., 2018; Wang et al., 2020) but remains unresolved.

\section{A NEW TAPHONOMIC UNDERSTANDING OF THE CHARNIODISCUS CONCENTRICUS HOLOTYPE}

The 8 or 9 most apical primary branches of the holotype are negative epireliefs that are short, narrow, and rounded close to the axis and are directed slightly towards the frond base. There is no central stem preserved at the tip owing to the fact that the branches are impressed into sediment lying atop the plane of the inferred axial stem (Figure $\mathbf{3 A}$-green). These apical branches do not have any preserved transverse ornament, which is typical of some branches of the holotype. These transverse branches could have escaped preservation thus their actual existence cannot be ruled out. The arrangement of the branches is consistent with infolding of originally curved branches resulting in the impression of the interior surface of the branch into the sediments overlying the stem. This type of infolding preservation is also common in specimens attributed to C. arboreus from the Catalina Dome by Hofmann et al. (2008), (Figure 16 7-8).

The longer arcuate branches immediately adjacent to the apex of the holotype of $C$. concentricus are strongly curved and slightly imbricated towards the tip; there is no evidence of a clearly preserved axial stem, which may also be buried in this portion of the fossil (Figure 3A -blue, purple). We consider that branch curvature is due to the outfolding collapse of a sub-conical frond (Figures 5D-I). The strongly curved branches have sharp transverse ridges formed by sediment infilling the gaps between the transverse second order branches. Since these branches are outfolded, it would suggest that in life the external surfaces of the primary order ridge-like branches are what would be impressed into the sediment, and thus that the external surfaces were covered in transverse ridges. The curved portion of the outfolded set of branches on the right is observed in a slightly higher plane than the ambient plane (Figure 3-purple). 
Our study of the holotype supports the interpretation of the bottom-left proximal region of the frond being folded across the central axis (Jenkins and Gehling, 1978, Figures 4X,Y), albeit with some modifications. We interpret the first set of proximal branches (Figures $\mathbf{3 A}$ - orange) as being underfolded beneath the stem (Figures 5A-C). Evidence for this underfolding comes from: 1) the underfolded branches being the topographically lowest structures preserved in the holotype; and 2) the absence of a preserved stem, which would have lain above the underfolded branches and could not therefore have been impressed into the sediment.

The presence of underfolding is important for considering the life attitude of the organism because, in order to be able to underfold the branches, the stem cannot have lain upon the sediment surface in life. This leaves an erect or recumbent lifestyle as the only realistic modes of life. Additionally, underfolding would have necessarily occurred prior to the felling of the frond. Of the branches preserved in the proximal part of the frond, these are the only ones to preserve obliquely orientated secondary units in the inner surface of the branches.

The second set of proximal branches on the left-hand side of the fossil are preserved as impressions in sediment that lay at a higher level than the stem (Figures 3A-yellow) and above the ambient bedding plane (Figure 3B). The branches preserved at this higher level are the basis for inferring that Charniodiscus was a multifoliate frond (Dzik, 2002; Brasier and Antcliffe, 2009). However, we follow Jenkins and Gehling (1978) in considering that these branches were swept across the axis from left to right such that the bases of the branches are approximately aligned with the position of the stem, which we infer lay at a lower level below the sediment that casts the branches (Figures 5F-I). The sediment on top of the stem was either present inside the subconical frond during life, or shortly after death/felling, but before collapse and complete burial of the frond. In our model the stem is not preserved due to its position at a level below the rock surface (Figure 3B). The apparently smooth surface of the distal branches (Figures 3A-green) suggests that the inner surface of the branches may have been unornamented in the arcuate portion of the sub-conical frond.

\section{EVIDENCE FOR CHARNIODISCUS BEING A COLLAPSED SUB-CONICAL STRUCTURE}

The marked curvature of the outfolded branches of $C$. concentricus, the straight basally-directed infolded branches of the tip, and the preservation of sediment atop the central axis of much of the frond is most consistent with the frond being a collapsed sub-conical structure with a more flattened side adjacent to the stem (Figure 2A). The curvature of the branches suggests that the tips of the branches met in an apically-directed zipper-like fashion on the front side of the sub-conical frond. Actualistic modeling of the frond branches as they are preserved in the holotype is consistent with the tips of the branches meeting in a chevron-like seam when reconstructed (Figure 5A). Since the bases of the branches meet the axis at nearly $90^{\circ}$ it seems logical that these branches have not been greatly modified by compression; this suggests that the basal portion of the branches were rather flat, producing a flattened base to the sub-conical frond (Figures 5-7).

The pronounced curvature of the apical branches is a prominent feature of Charniodiscus concentricus and a significant difference between it and Arborea (Jenkins and Gehling, 1978; Laflamme et al., 2004). Other arboreomorphs with strongly curved branches in the Avalon assemblage include Charniodiscus procerus (Laflamme et al., 2004; Figure 6) and another un-named Charniodiscus species with broad strongly arcuate branches (Figure 7). We consider all of these forms to be species of Charniodiscus and each of them probably had a similar conical frond without a "backing sheet" (sensu Dunn et al., 2019).

Arboreomorphs without pronounced branch curvature include: Charniodiscus arboreus (sensu Hofmann et al., 2008, fig. 16 7-8); C. longus (Figure 2D); C. oppositus; and C. spinosus (Figure 2C). Most if not all of these taxa also have a prominent backing sheet and are thus likely to be species of Arborea.

We thus consider that there are two different unipolar bifoliate frond morphologies within the Arboreomorpha: 1) sub-conical fronds with arboreomorph branching and no backing sheet, typical of Charniodiscus; and 2) planar fronds with a prominent backing sheet on one side and arboreomorph branching on the other, which are attributable to Arborea.

\section{SYSTEMATIC PALAEONTOLOGY}

Phylum Indet.

Clade Arboreomorpha.

Genus Charniodiscus Ford 1958.

Type species. - Charniodiscus concentricus, described from the Charnian Supergroup of the UK (Ford, 1958).

Emended generic diagnosis. - Unipolar frondose arboreomorphs with basal disc, stem, a bifoliate frond without a backing sheet and loosely constrained branches. The bases of the branches are commonly straight and attached to the stem at nearly right angles but are distally curved forming a sub-conical frond in life. Outer surface of the branches of the sub-conical frond has transverse ridges orthogonal to the long axis of the branches. The internal surface of the branch has similar oblique ridges close to the junction with the stem.

Discussion. - The species of Charniodiscus considered valid herein are $C$. concentricus and $C$. procerus. The status of $C$. yorgensis requires restudy of the type material that is beyond the scope of this study. All other taxa hitherto attributed to Charniodiscus (C. arboreus, C. longus, C. oppositus, and C. spinosus) should likely be considered to be species of Arborea but require further study and comparison with the type species (cf. Laflamme et al., 2018; Wang et al., 2020). The branches of $C$. concentricus are considered to be homologous with the pea-podlike units of Arborea (cf. Dunn et al., 2019).

Charniodiscus concentricus Ford 1958.

Emended specific diagnosis. - Charniodiscus with basal disc, stem, and a bifoliate frond, lacking a supporting backing sheet, composed of approximately 25 independent branches that were 
1958 Charniodiscus concentricus Ford, p. 212 pl. 13, fig. 2-3 (originally as a form taxon, basal disc of Charnia)

1963 Charniodiscus concentricus Ford, pl. 1, fig.1 a-d

non 1966 Charniodiscus arboreus Glaessner and Wade, pl. 102, fig. 1-2

non 1966 Charniodiscus longus Glaessner and Wade, pl. 100, fig. 4

non 1978 Charniodiscus oppositus Jenkins and Gehling, p. 204 pl. 3, fig. 4

? $1999 \quad$ Charniodiscus yorgensis Borchvardt and Nessov, p. 54, text-fig. 2

2004 Charniodiscus procerus Laflamme et al. p. 830, fig. 3

non 2004 Charniodiscus spinosus Laflamme et al., p. 830-831, fig. 3-4

Type species. - Charniodiscus concentricus, described from the Charnian Supergroup of the UK (Ford, 1958).

strongly curved inward and upward in life to form a sub-conical frond, which becomes lanceolate to ovate upon collapse/compression.

Description. - Charniodiscus concentricus has a round basal disc bearing concentric rings without a prominent central boss, from which a broad stem emerges. The stem is short $(\sim 4 \mathrm{~cm})$ and relatively poorly preserved in the holotype. The primary arboreomorph branches are attached to the lateral margins of the stem. The impression of the frond is bifoliate and lanceolate to ovate in outline $(16.2 \mathrm{~cm}$ length: $6.3 \mathrm{~cm}$ wide). The external distal portion and the internal proximal section of the primary branches have secondary order transverse barlike morphology. There is no evidence of fractal branching pattern characteristic of the Rangeomorpha.

Discussion. - The junction between the branches and the stem in the holotype Charniodiscus concentricus is not preserved except at the base. The stem of the holotype is poorly preserved, especially in comparison to $C$. procerus from the Newfoundland
Ediacaran biota (Figure 6). This may relate to a combination of different tissue composition/resilience and different body postures in life. Curvature of the branches in C. concentricus and $C$. procerus is considerably more pronounced than in other species of the genus, occasionally leading to compromised preservation of the branches towards distal sections (Figure 6).

Charniodiscus concentricus has parallel transverse ridges preserved in the external distal-most section of certain apical branches and in the internal side of the proximalmost section of certain proximal branches. However, there is no evidence of the fractal branching pattern which would be required to assign the genus to the Rangeomorpha (Brasier et al., 2012). Additionally, the absence of the prominent backing sheet of Arborea further distinguishes Charniodiscus from Arborea. Our reinterpretation of the holotype is significantly different from previous models (Ford, 1958; Jenkins and Gehling, 1978; Dzik, Charnia]

1963 Charniodiscus concentricus Ford, pl. 1, fig.1 a-d [description of frond associated with basal disc]

$1978 \quad$ Charniodiscus concentricus Jenkins and Gehling, p. 350-352, fig. 2, 4

$2002 \quad$ Charniodiscus concentricus Dzik, p. $322-323$

2009 Charniodiscus concentricus Brasier and Antcliffe, p. 375-377, fig. 12-14

2012 Charniodiscus concentricus Brasier et al., p. 1109-1114, fig. 3

2017 Charniodiscus concentricus Liu et al. fig. 3 a-c 


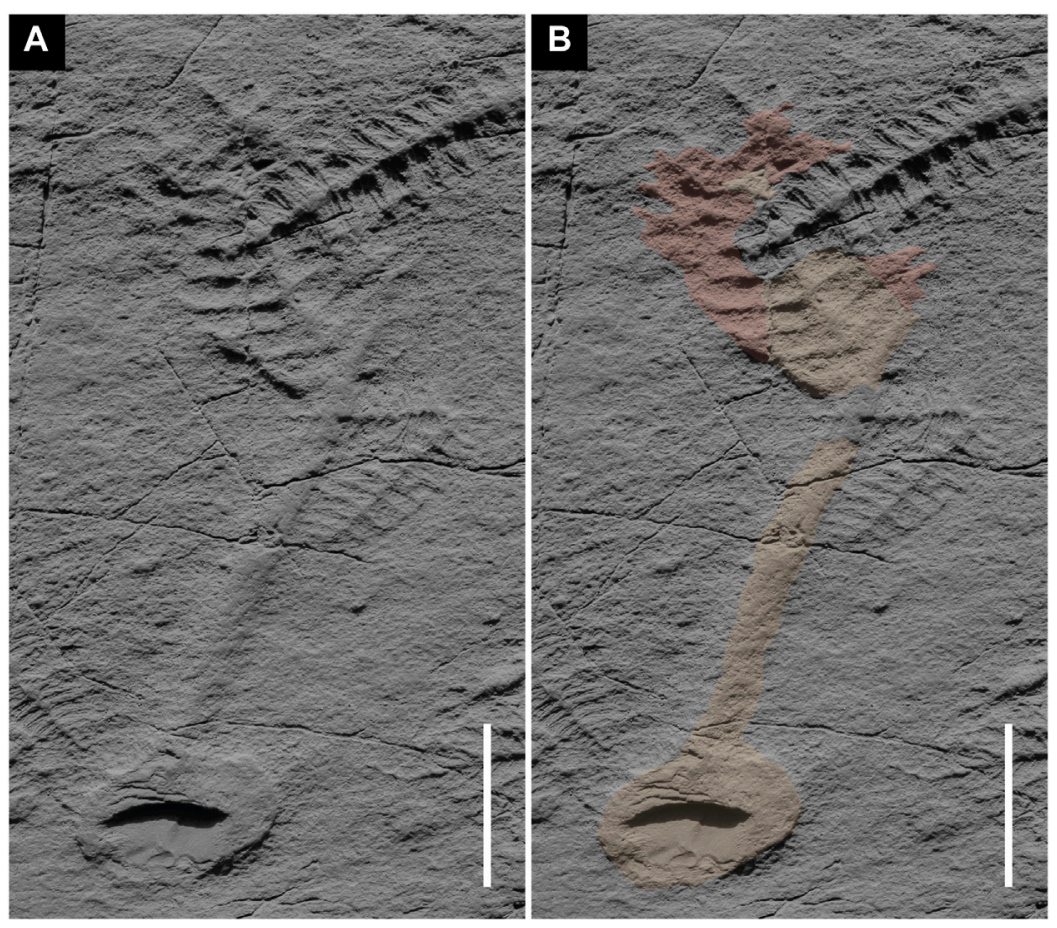

FIGURE 6 | Charniodiscus procerus from the so-called "Seilacher's Corner", upper part of the Mistaken Point Formation ("E'"-surface) at Mistaken Point, Newfoundland. (A) cast. (B) Basal disc, stem and flat basal section of the branches meeting the central axis at $~ 90^{\circ}$ in orange; apical section of the branches showing pronounced curvature in red. Scale bars $3 \mathrm{~cm}$. Jesmonite cast of field specimen. Not retrodeformed.

2002; Brasier and Antcliffe, 2009; Brasier et al., 2012) in that the holotype is herein demonstrated to be bifoliate, non-fractal, lacking the backing sheets characteristic of Arborea, and having a conical shape defined by Arboreomorph-type branches (Laflamme and Narbonne, 2008).

\section{MODE OF LIFE OF CHARNIODISCUS CONCENTRICUS}

Reconstructions of most frondose Ediacaran taxa have followed Glaessner (1984) in depicting them as being erect, pennatulacean-

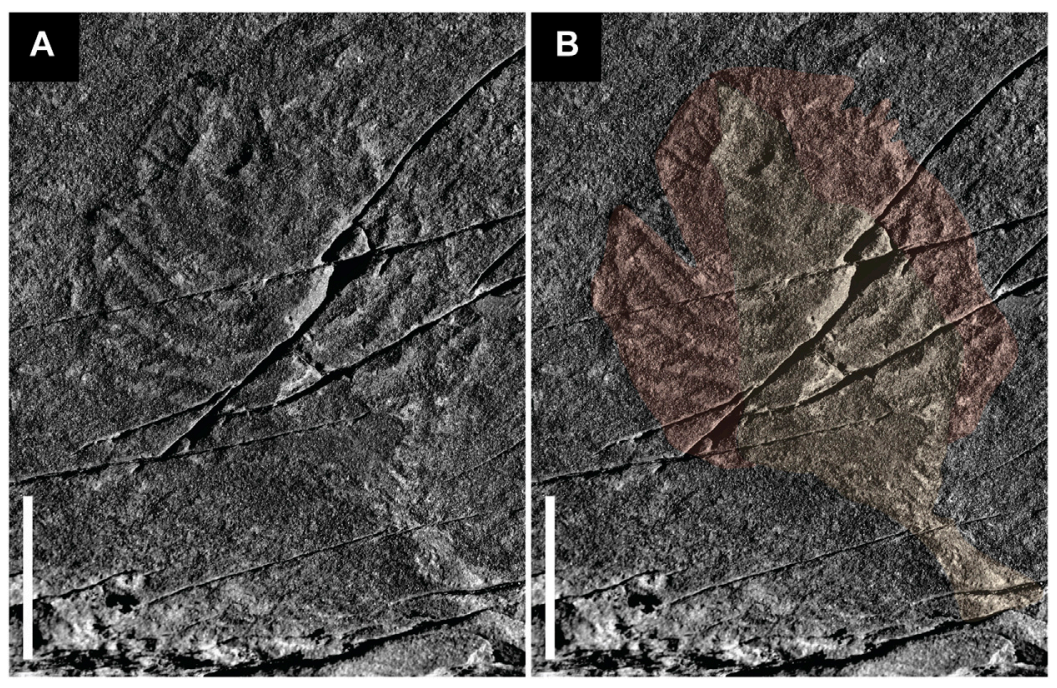

FIGURE 7|Charniodiscus sp. from the Mistaken Point Formation ("D" -surface) at Mistaken Point, Newfoundland. (A) field photography of the specimen. (B) Stem and flat basal section of the branches meeting the central axis at $\sim 90^{\circ}$ in orange; apical section of the branches showing pronounced curvature in red. Scale bars $3 \mathrm{~cm}$. Field photography. Not retrodeformed. 
like organisms and the coining of descriptive terms such as stems, basal disc, and frondlets belies attempts to draw analogies to extant taxa (e.g., algae). This imparts an implicit bias towards palaeobiological reconstructions presenting many Ediacaran organisms as having an erect mode of life. This standard paradigm has recently been challenged (McIlroy et al., 2020, McIlroy et al., 2021), in an assertion that the null hypothesis for orientation should be the preserved (i.e., reclined on the sediment) position unless there is evidence to the contrary.

Arboreomorphs generally possess well-preserved basal discs, possibly representing anchoring structures that were partially immersed in the sediment (Burzynski and Narbonne, 2015; Tarhan et al., 2015). Some discs have folds consistent with originally inflated bodies that eventually experienced collapse (Dunn et al., 2019; McIlroy et al., 2021) which might imply the presence of some form of cnidarian-like hydrostatic skeleton in life. Since some species of Charniodiscus and Arborea commonly have poor preservation of the stem, this can be taken to suggest that: 1) the stem did not lie upon the seafloor surface during preservation (i.e., stems arched upward due to the displacement of the frond allowing deposition of sediment between the stem and the bedding plane; Figure 4); or 2) stems of some taxa decayed more rapidly than the other tissues. The stem of the Charniodiscus concentricus holotype is remarkably flat, and relatively poorly preserved. The stem, as previously interpreted, is apparently offset from the axis of the frond. We consider that this is an artifact of the underfolding of the branches under the stem, which obscures one margin of it (Figure 3A). There is no evidence of swing marks associated with the holotype unlike some frondose taxa (Jensen et al., 2018) and only erect (e.g., Glaessner and Daily, 1959; Glaessner, 1984) or recumbent (Laflamme et al., 2018) modes of life are consistent with underfolding and the commonly poor preservation of the stem. The impression of the upper parts of the branches into sediment that lay above the level of the stem strongly suggests the presence of sediment above the stem before post-mortem collapse of the frond. This taphonomic mode is consistent with a curved front surface to the bifoliate frond.

Additional evidence for sub-conical frondose arboreomorphs comes from the recent discovery of a specimen of Charniodiscus sp. preserved in full relief in a thin Tc sand unit immediately above the Spaniard's Bay assemblage in Newfoundland (Narbonne et al., 2009; Brasier et al., 2013). The three-dimensional morphology of the Charniodiscus frond can be inferred from the well-preserved collapsed sub-conical frond with indication of the transverse cross section (Figure 8). The frond is characterized by basallydirected infolding collapse of the frond with the junctions between the tips of opposing primary branches being well preserved. This mode of infolding collapse is also seen in the very tip of the holotype of $C$. concentricus and the partial fill of the originally sub-conical Spaniard's Bay specimen above the level of the stem is similar to that of parts of the holotype (Figures 3A-green). The primary branches of the Spaniard's Bay Charniodiscus have no evidence for fractal rangeomorph branching, further supporting the non-rangeomorph nature of Charniodiscus.

The most common Avalonian arboreomorph with strongly curved broad branches is Charniodiscus procerus (Laflamme et al.,

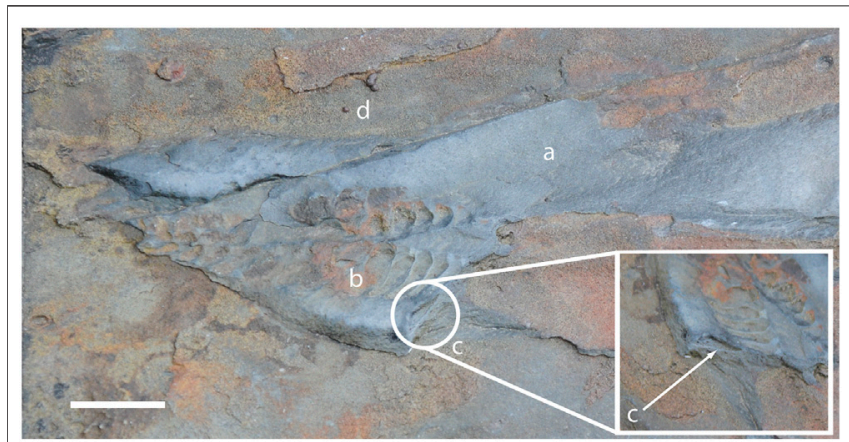

FIGURE 8 | Charniodiscus sp. from Spaniard's bay, Newfoundland. (A) Overlying siltstone. (B) collapsed sub-conical frond preserved in sandstone. (C) cross section view. (D) underlying siltstone. Scale bar $1 \mathrm{~cm}$. Field photography. Not retrodeformed.

2004, Figure 3A) which has a central triangular section adjacent to the stem that is typically well preserved as deep negative epireliefs (Figures 6- orange). In well preserved material, the arcuate portion of branches extends from the triangular portion in a manner similar to the more numerous very narrow branches close to the tip of $C$. concentricus. The distal curved portion of the primary branches of $C$. procerus (Figures 6- red) are interpreted-by analogy with $C$. concentricus and C. sp. from Spaniards Bay-as casts of the impressions made by the external surfaces of the curved portion of the conical frond that we consider to be typical of Charniodiscus.

In contrast to the flattened stem of $C$. concentricus and the poorly preserved stem of other Arboreomorphs and Rangeomorphs in the same Newfoundland assemblages (Laflamme et al., 2004; Laflamme et al., 2012), the stem of $C$. procerus is generally well preserved and covered in matground textures (Figure 6) and even other reclining taxa such as Fractofusus. As such it would seem that $C$. procerus conforms to the null hypothesis of McIlroy et al. (2020), McIlroy et al.(2021) that unless there is positive evidence to support an erect mode of life, the stem of the frond should be considered to have lain on or in the seafloor during life. However, the presence of a specimen of Fractofusus below the frond of one specimen may also suggest that the frondose portion may have been erect arising from the end of the reclined stem, only falling post-mortem onto the seafloor on top of the aforementioned Fractofusus (Figure 6). A second hitherto undescribed Charniodiscus with highly curved broad primary branches with transverse ornament is also present in the Newfoundland assemblage (Figure 7).

\section{PALAEOBIOLOGICAL MODEL OF CHARNIODISCUS}

The original cnidarian affinities of frondose Ediacaran organisms (e.g., Charnia and Bragdatia) have recently been questioned (e.g., Brasier and Antcliffe, 2004; Narbonne, 2004, Narbonne, 2005; 
Antcliffe and Brasier, 2008), though their utility as functional morphological analogs may still be valid (Dunn et al., 2019). If Charniodiscus is accepted as a sub-conical stemmed frondose arboreomorph, then it might function biomechanically erect in the water column like most pennatulaceans (cf. Kushida et al., 2020, Figure 2A) in which case it might draw water up through the cone by Bernoulli effect. The same morphotype might also be an adaption to funnel water if held in a recumbent or reclined position parallel to the seafloor, either with the cone directed into or away from the current. If held in a recumbent or reclining position the broad end of the cone would face into the current in the manner of a windsock. In erect or seafloor-parallel recumbent positions, the frond would be exposed to the water column as a foliate feeding structure. This could result in ecological benefits from resource partitioning and reduced competition in ecosystems with crowded lower tiers. Both absorption of dissolved matter and filter feeding strategies are congruent with tiered epifaunal models (Clapham and Narbonne, 2002; Ghisalberti et al., 2014).

While presumed erect or recumbent positions are plausible body postures for some taxa, it remains uncertain for some others which pose important challenges to the interpretation of Ediacaran tiering models (McIlroy et al., 2021). The stems that connect holdfasts and fronds in arboreomorphs (e.g. Arborea, C. concentricus, C. spinosus) are poorly preserved (Figure 2). This is likely due to the arching of the stem as fronds are felled from their erect or recumbent position onto the seafloor (cf. Glaessner and Daily, 1959; Glaessner, 1984; McIlroy et al., 2021). In contrast, $C$. procerus generally has a long well-preserved stem with a semicircular cross section and no supporting evidence for erect or recumbent stem positions (Figure 6). This suggests that in life the stem of $C$. procerus lay flat on the seafloor implying exposure of the lower surface to sedimentary microbial ecosystems and pore water hypoxia (cf. Dufour and McIlroy, 2017). The stem could have therefore had other functions than merely structural support, possibly establishing symbiotic relationships with chemosynthetic, sulphur-oxidising bacteria to mitigate the elevated toxicity (McIlroy et al., 2021). Whether the stem of a Charniodiscus was reclined on/in the sediment or held in a recumbent position just above it, there is significant potential for sediment to become trapped inside the sub-conical frondose portion. This is especially true during periods of rapid sediment influx, accumulating at a level above the stem and into which the distal portion of the branches might become impressed (Figures 3A-green).

C. procerus shows flat proximal sections of the primary branches meeting the central axis at nearly right angles providing support for the distally curved section of the same branches in a similar fashion to other Charniodiscus specimens (Figures 7, 8). These branches were curved inward and apically directed, forming a reclined sub-conical or erect frondose portion whose lumen would be exposed to the water column. The subconical structure would funnel water in a similar manner as in seafloor-parallel recumbent positions.

It has been considered that Ediacaran fronds with primary branches annexed together or having a "backing sheet" could not have fed like the Pennatulacea, which require water flow between primary branches (Seilacher, 1992). Our functional morphological understanding of Charniodiscus concentricus as a recumbent (sediment-parallel) or erect frond allows funneled flow between the branches of the frond, which was held slightly above the benthic boundary layer. The branches of $C$. concentricus are interpreted as fascicled, loosely constrained branches not supported by a backing sheet of tissue similar to some Shibatan charnids (Xiao et al., 2021, Figures 5C-E) or Arborea spp. However, due to the lack of preserved specialized zooids or feeding structures, the feeding mechanisms of Charniodiscus and other arboreomorphs remain uncertain but may have included osmotrophy and/or filter feeding (Laflamme et al., 2018).

\section{Taxonomic Consideration of Other Charniodiscus Species}

Throughout the $\sim 35$ My of evolutionary history of the Ediacaran biota we observe a contrast between highly unique morphological disparity (Shen et al., 2008) and low taxonomic diversity (Waggoner, 2003). This has led to the creation of numerous monospecific genera, a lack of unified consensus regarding higher taxonomic ranks (Xiao and Laflamme, 2009), and genus and clade-level taxonomic inconsistencies (Brasier and Antcliffe, 2009; Liu et al., 2015; Laflamme et al., 2018; Wang et al., 2020).

Cladistic classification for Ediacaran macrofossils based on branching architecture, body symmetry, and growth parameters (Erwin et al., 2011) recognized the clade Arboreomorpha, which encompasses bifoliate fronds bearing annexed primary branches attached to a dorsal sheet. Those primary branches were considered to have orthogonal teardrop-shaped secondary branches. All species of Charniodiscus and Arborea were included in this clade except for C. concentricus. Dececchi et al. (2017) supported Erwin et al. (2011), using autapomorphically-constructed clades, in the recognition of the clade Arboreomorpha, which was defined as having spherical to hemispherical secondary branches with no further orders of branching and lacking a modular petalodium. We consider these transverse ridges to be semicircular. Arboreomorpha was also reported to show conserved inflating growth patterns and diagnostic numbers of branches (Laflamme et al., 2004).

In the light of our work there are several bifoliate planar arboreomorphs that require further taxonomic revision, including:

1) C. longus Glaessner and Wade, 1966 (formerly Rangea longa and Glaessnerina longa; Fedonkin et al., 2007), an elongate and lanceolate frond bearing at least 40 primary branches and uniform secondary subdivisions without a preserved stem or basal disc (Glaessner and Wade, 1966; Laflamme et al., 2004; Wang et al., 2020). The branching is clearly Arborea-like and there appears to be a prominent backing sheet (Figure 2D), indicating that it should likely be considered as Arborea longa.

2) The endemic Newfoundland species C. spinosus, which has a backing sheet, a stem that is typically poorly preserved, and an apical spine. Careful photography of the branching allows the recognition of Arborea-like branches (Figure 2C), suggesting that this species should also be included in Arborea, as Arborea spinosa. 
3) Material from the Bonavista Peninsula of Newfoundland described as $C$. arboreus and $C$. sp. by Hofmann et al. (2008) bear little resemblance to the type material of Arborea (Glaessner and Wade, 1966) in being non-tapering without prominent holdfasts or robust stems. Specimens from Bonavista are commonly preserved in a manner akin to the tip of $C$. concentricus (i.e., collapse infolding) and should likely be retained within Charniodiscus, probably as a distinct species with fewer branches than the holotype.

\section{CONCLUSION}

The inferred multifoliate nature of the holotype of Charniodiscus concentricus (Dzik, 2002; Brasier and Antcliffe, 2009) made it considerably different from all the other (bifoliate) species of the genus. Newfoundland species of Charniodiscus have hitherto been retained in the genus, but separated from Arborea based on the inferred rangeomorph-like branching architecture of Charniodiscus (Brasier and Antcliffe, 2009). Our taphonomic and morphological reinterpretation of Charniodiscus concentricus allows the resolution of existing taxonomic inconsistencies. The pronounced curvature of the outfolded branches, taken alongside the straight basallydirected infolded collapsed branches of the tip, the observed differential branch folding, and the preservation of sediment atop the central axis of much of the frond suggests that the frond was a bifoliate collapsed sub-conical structure with apically directed branches meeting in an-echelon fashion characterized by Arborea-type branching lacking a continuous sheet of tissue.

Based on the poorly preserved stem in Charniodiscus concentricus-likely due to the arching that would occur during the felling of the frond to the seafloor from its erect or recumbent life position-and the underfolding of the branches under the stem we infer an erect or recumbent lifestyle as the only plausible options for life attitude. C. concentricus as reconstructed herein (Figure 5) could have functioned biomechanically either erect in the water column like a cone on a stick, similar to the mode of life of many pennatulacean cnidarians, or if held in a recumbent position parallel to the seafloor the cone might have functioned to funnel water over and possibly between the branches.

Charniodiscus procerus generally has high relief well-preserved stems with no additional evidence for erect or recumbent body postures in life. This is likely due to a dominantly reclining position of the organism, which would have had the stem laid upon or even partly embedded within the matground. This challenges the paradigm that all Ediacaran stemmed taxa were erect fronds in the water column (e.g. Vixseboxse et al., 2021). Similarly, the distal curved portions of the primary branches of $C$. procerus are interpreted-by analogy with C. concentricus and $C$. sp. from Spaniards Bay-as casts of the impressions made by the external surfaces of the curved portion of the conical frond smothering the surrounding matground due to post-mortem outfolding.

We propose emendation of the generic diagnosis of Charniodiscus to encompass bifoliate arboreomorphs with sub- conical petalodiums, while retaining Arborea for the bifoliate planar arboreomorphs with a backing sheet. As such we infer two distinct frond morphologies: 1) sub-conical fronds with arboreomorph branching which we consider to be typical of Charniodiscus; versus 2) planar foliate sheets of the genus Arborea in which the arboreomorph branching is considered to be on the front surface. Our model supports the retention of both Charniodiscus and Arborea, solving the existing taxonomic inconsistencies. Additionally, we find no evidence of rangeomorph-type fractal branching in Charniodiscus and thus reject its inclusion in the Rangeomorpha.

The non-vertical (recumbent or reclining) life attitude invoked for Charniodiscus spp. herein is based on our improved taphonomic understanding of the genus and is consistent with other proposals for Ediacaran fronds (Laflamme and Narbonne, 2008; Laflamme et al., 2018). We also note here that the presence of a backing sheet in Arborea spp. would be a significant impediment to flow increasing the aspect ratio of the frond. This suggests that it might also be an adaptation to modify the life attitude of Arborea spp. to become recumbent in a current, allowing for current orientation of the frond and increased turbulent flow over the frond surface.

\section{DATA AVAILABILITY STATEMENT}

The original contributions presented in the study are included in the article/supplementary material, further inquiries can be directed to the corresponding author.

\section{AUTHOR CONTRIBUTIONS}

DP-P and DM conceived the project. DP-P and CM constructed figures. DP-P, CM, RT, RN, and DM analyzed the data and prepared the manuscript.

\section{FUNDING}

Funding was provided to D. Mc. by Discovery Grant and Discovery Accelerator Supplement awards from the Natural Sciences and Engineering Research Council, which are acknowledged with thanks.

\section{ACKNOWLEDGMENTS}

Jenna Neville and Giovanni Pasinetti are thanked for their assistance through both discussions related to this topic and their support in the field. We acknowledge with thanks the Oxford University Museum of Natural History for access to the Brasier collections. Fieldwork and fossil casting in Newfoundland was conducted under permit from the Parks and Natural Areas Division of the Government of Newfoundland and Labrador. This project was supported by an NSERC Discovery Grant and Discovery Accelerator Supplement to DMc. 


\section{REFERENCES}

Antcliffe, J. B., and Brasier, M. D. (2008). Charnia at 50: Developmental Analysis of Ediacaran Fronds. Paleontology 64 (6), 1753-2284. doi:10.1111/j.14754983.2007.00738.x

Borchvardt, D. V., and Nessov, L. A. (1999). New Records of Metaphytes from the Vendian (Precambrian) of Zimnii Bereg of the White Sea. Tr. Zool. Inst. Ross. Akad. Nauk. 277, 50-57.

Brasier, M., and Antcliffe, J. (2004). Decoding the Ediacaran Enigma. Science 305, 1115-1117. doi:10.1126/science.1102673

Brasier, M. D., and Antcliffe, J. B. (2009). Evolutionary Relationships within the Avalonian Ediacara Biota: New Insights from Laser Analysis. J. Geol. Soc. Lond. 166 (2), 363-384. doi:10.1144/0016-76492008-011

Brasier, M. D., Antcliffe, J. B., and Liu, A. G. (2012). The Architecture of Ediacaran Fronds. Palaeontology 55 (5), 1105-1124. doi:10.1111/j.14754983.2012.01164.x

Brasier, M. D., Liu, A. G., Menon, L., Matthews, J. J., McIlroy, D., and Wacey, D. (2013). Explaining the Exceptional Preservation of Ediacaran Rangeomorphs from Spaniard's Bay, Newfoundland: A Hydraulic Model. Precambrian Res. 231, 122-135. doi:10.1016/j.precamres.2013.03.013

Burzynski, G., and Narbonne, G. M. (2015). The Discs of Avalon: Relating Discoid Fossils to Frondose Organisms in the Ediacaran of Newfoundland. Can. Palaeogeogr. Palaeocl. 434, 34-45. doi:10.1016/ j.palaeo.2015.01.014

Clapham, M. E., and Narbonne, G. M. (2002). Ediacaran Epifaunal Tiering. Geol 30, 627-630. doi:10.1130/0091-7613(2002)030<0627:eet>2.0.co;2

Dececchi, T. A., Narbonne, G. M., Greentree, C., and Laflamme, M. (2017). Relating Ediacaran Fronds. Paleobiology 43 (2), 171-180. doi:10.1017/pab.2016.54

Dufour, S. C., and McIlroy, D. (2017). Ediacaran Pre-placozoan Diploblasts in the Avalonian Biota: the Role of Chemosynthesis in the Evolution of Early Animal Life. Geol. Soc. Lond. Spec. Publ. 448, 211-219. doi:10.1144/sp448.5

Dunn, F. S., Liu, A. G., and Gehling, J. G. (2019). Anatomical and Ontogenetic Reassessment of the Ediacaran Frond Arborea arborea and its Placement within Total Group Eumetazoa. Palaeontology 62, 851-865. doi:10.1111/pala.12431

Dzik, J. (2002). Possible Ctenophoran Affinities of the Precambrian "sea-pen" Rangea. J. Morphol. 252, 315-334. doi:10.1002/jmor.1108

Erwin, D. H., Laflamme, M., Tweedt, S. M., Sperling, E. A., Pisani, D., and Peterson, K. J. (2011). The Cambrian Conundrum: Early Divergence and Later Ecological success in the Early History of Animals. Science 334 (6059), 1091-1097. doi:10.1126/science.1206375

Fedonkin, M. A., Gehling, J. G., Grey, K., Narbonne, G. M., and Vickers-Rich, P. (2007). The Rise of Animals: Evolution and Diversification of the Kingdom Animalia. Baltimore, MD, United States: JHU Press.

Fedonkin, M. A. (1985). "Systematic Description of Vendian Metazoa," in The Vendian System: Historic-Geological and Palaeontological Basis. Editor B. S. Sokolov and A. B. Ivanovskiy (PaleontologyMoscow: Nauka), 1, 70-107.

Ford, T. D. (1958). Pre-cambrian Fossils from Charnwood Forest. Proc. Yorkshire Geol. Soc. 31, 211-217. doi:10.1144/pygs.31.3.211

Ford, T. D. (1962). The Oldest Fossils. New Sci. 15, 191-194.

Ford, T. D. (1963). The Pre-cambrian Fossils of Charnwood Forest. Trans. Leicester Lit. Phil. Soc. 57, 57-62.

Gehling, J. G. (1999). Microbial Mats in Terminal Proterozoic Siliciclastics: Ediacaran Death Masks. Palaios 14, 40-57. doi:10.2307/3515360

Gehling, J. G. (1991). The Case for Ediacaran Fossil Roots to the Metazoan Tree. Mem. Geol. Surv. India. 20, 181-224.

Ghisalberti, M., Gold, D. A., Laflamme, M., Clapham, M. E., Narbonne, G. M., Summons, R. E., et al. (2014). Canopy Flow Analysis Reveals the Advantage of Size in the Oldest Communities of Multicellular Eukaryotes. Curr. Biol. 24, 305-309. doi:10.1016/j.cub.2013.12.017

Glaessner, M. F., and Daily, B. (1959). The Geology and Late Precambrian Fauna of the Ediacara Fossil reserve. Rec. Aust. Mus. 13, 369-401.

Glaessner, M. F. (1984). The Dawn of Animal Life: A Biohistorical Study. Cambridge, United Kingdom: Cambridge University Press.

Glaessner, M. F., and Wade, M. (1966). The Late Precambrian Fossils from Ediacara, South Australia. Palaeontology 9, 599-628.

Grazhdankin, D. (2014). Patterns of Evolution of the Ediacaran Soft-Bodied Biota. J. Paleontol. 88, 269-283. doi:10.1666/13-072
Herringshaw, L. G., Callow, R. H., and McIlroy, D. (2017). Engineering the Cambrian Explosion: the Earliest Bioturbators as Ecosystem Engineers. Geol. Soc. Lond. Spec. Publ. 448, 369-382. doi:10.1144/sp448.18

Hofmann, H. J., O'Brien, S. J., and King, A. F. (2008). Ediacaran Biota on Bonavista Peninsula, Newfoundland, Canada. J. Paleontol. 82, 1-36. doi:10.1666/06-087.1

Ivantsov, A. Y. (2016). Reconstruction of Charniodiscus yorgensis (Macrobiota from the Vendian of the White Sea. Paleontol. J. 50, 1-12. doi:10.1134/ s0031030116010032

Jenkins, R. J. (1992). "Functional and Ecological Aspects of Ediacaran Assemblages," in Origin and Early Evolution of the Metazoa (Boston, MA: Springer).

Jenkins, R. J. F., and Gehling, J. G. (1978). A Review of the Frond-like Fossils of the Ediacara Assemblage. Rec. Aust. Mus. 17, 347-359.

Jensen, S., Högström, A. E. S., Almond, J., Taylor, W. L., Meinhold, G., Høyberget, M., et al. (2018). Scratch Circles from the Ediacaran and Cambrian of Arctic Norway and Southern Africa, with a Review of Scratch circle Occurrences. Bull. Geosci. 93, 287-304. doi:10.3140/bull.geosci.1685

Kenchington, C., and Wilby, P. R. (2014). Of Time and Taphonomy: Preservation in the Ediacaran. [Bookchapter]. London, United Kingdom: Cambridge University Press. Available at: https://www.repository.cam.ac.uk/handle/ $1810 / 247083$.

Kushida, Y., Higashiji, T., and Reimer, J. D. (2020). First Observation of Mole-like Burrowing Behavior Observed in a Sea Pen. Mar. Biodivers. 50, 1-9. doi:10.1007/s12526-020-01054-y

Laflamme, M., Flude, L. I., and Narbonne, G. M. (2012). Ecological Tiering and the Evolution of a Stem: the Oldest Stemmed Frond from the Ediacaran of Newfoundland, Canada. J. Paleontol. 86, 193-200. doi:10.1666/11-044.1

Laflamme, M., Gehling, J. G., and Droser, M. L. (2018). Deconstructing an Ediacaran Frond: Three-Dimensional Preservation of Arborea from Ediacara, South Australia. J. Paleontol. 92, 323-335. doi:10.1017/jpa.2017.128

Laflamme, M., Narbonne, G. M., and Anderson, M. M. (2004). Morphometric Analysis of the Ediacaran Frond Charniodiscus from the Mistaken Point Formation. Newfoundland. J. Paleontol. 78, 827-837. doi:10.1666/00223360(2004)078<0827:maotef $>2.0$. co;2

Laflamme, M., and Narbonne, G. M. (2008). Ediacaran Fronds. Palaeogeogr. Palaeoclimatol. Palaeoecol. 258, 162-179. doi:10.1016/j.palaeo.2007.05.020

Liu, A. G. (2016). Framboidal Pyrite Shroud Confirms the 'death Mask' Model for Moldic Preservation of Ediacaran Soft-Bodied Organisms. Palaios 31, 259-274. doi:10.2110/palo.2015.095

Liu, A. G., Kenchington, C. G., and Mitchell, E. G. (2015). Remarkable Insights into the Paleoecology of the Avalonian Ediacaran Macrobiota. Gondwana Res. 27, 1355-1380. doi:10.1016/j.gr.2014.11.002

Liu, A. G., McIlroy, D., Antcliffe, J. B., and Brasier, M. D. (2011). Effaced Preservation in the Ediacara Biota and its Implications for the Early Macrofossil Record. Palaeontology 54, 607-630. doi:10.1111/j.1475-4983.2010.01024.x

Liu, A. G., McIlroy, D., and Brasier, M. D. (2010). First Evidence for Locomotion in the Ediacara Biota from the 565 Ma Mistaken Point Formation. Newfoundland. Geology. 38, 123-126. doi:10.1130/g30368.1

Liu, A. G., Menon, L. R., Shields, G. A., Callow, R. H., and McIlroy, D. (2017). Martin Brasier's Contribution to the Palaeobiology of the Ediacaran-Cambrian Transition. Geol. Soc. Lond. Spec. Publ. 448, 179-193. doi:10.1144/sp448.9

Mapstone, N. B., and McIlroy, D. (2006). Ediacaran Fossil Preservation: Taphonomy and Diagenesis of a Discoid Biota from the Amadeus Basin, central Australia. Precambrian Res. 149, 126-148. doi:10.1016/ j.precamres.2006.05.007

Matthews, J. J., Liu, A. G., Yang, C., Mcllroy, D., Levell, B., and Condon, D. J. (2021). Achronostratigraphic Framework for the Rise of the Ediacaran Macrobiota: New Constraints from Mistaken Point Ecological Reserve. Newfoundland. Bull. Geol. Soc. Am. 133, 612-624. doi:10.1130/gsab.s.12509984.v1

McIlroy, D., Brasier, M. D., and Lang, A. S. (2009). Smothering of Microbial Mats: Implications for the Ediacaran Biota. J. Geol. Soc. Lond. 166, 1117-1121. doi:10.1144/0016-76492009-073

McIlroy, D., Brasier, M. D., and Moseley, J. B. (1998). The Proterozoic-Cambrian Transition within the 'Charnian Supergroup' of central England and the Antiquity of the Ediacara Fauna. J. Geol. Soc. Lond. 155, 401-411. doi:10.1144/gsjgs.155.2.0401

McIlroy, D., Dufour, S. C., Taylor, R., and Nicholls, R. (2021). The Role of Symbiosis in the First Colonization of the Seafloor by Macrobiota: Insights 
from the Oldest Ediacaran Biota (Newfoundland, Canada). Biosystems 205, 104413. doi:10.1016/j.biosystems.2021.104413

McIlroy, D., Hawco, J., McKean, C., Nicholls, R., Pasinetti, G., and Taylor, R. (2020). Palaeobiology of the Reclining Rangeomorph Beothukis from the Ediacaran Mistaken Point Formation of southeastern Newfoundland. Geol. Mag., 1-15. doi:10.1017/s0016756820000941

McIlroy, D., and Horák, J. M. (2006). "Neoproterozoic: the Late Precambrian Terranes that Formed Eastern Avalonia," in The Geology of England and Wales. Editors P. R. Brenchley and P. F. Rawson (Bath, UK: Geological Society Publishing House), 9-25.

Mcllroy, D., and Logan, G. A. (1999). The Impact of Bioturbation on Infaunal Ecology and Evolution during the Proterozoic-Cambrian Transition. Palaios $14,58-72$.

Murphy, J. B., Pisarevsky, S. A., Nance, R. D., and Keppie, J. D. (2004). Neoproterozoic-Early Paleozoic Evolution of Peri-Gondwanan Terranes: Implications for Laurentia-Gondwana Connections. Int. J. Earth Sci. 93, 659-682. doi:10.1007/s00531-004-0412-9

Narbonne, G. M., and Hofmann, H. J. (1987). Ediacaran Biota of the Wernecke Mountains, Yukon, Canada. Palaeontology 30, 647-676.

Narbonne, G. M., Laflamme, M., Greentree, C., and Trusler, P. (2009). Reconstructing a Lost World: Ediacaran Rangeomorphs from Spaniard's Bay, Newfoundland. J. Paleontol. 83, 503-523. doi:10.1666/08-072r1.1

Narbonne, G. M. (2004). Modular Construction of Early Ediacaran Complex Life Forms. Science 305, 1141-1144. doi:10.1126/science.1099727

Narbonne, G. M. (2005). The Ediacara Biota: Neoproterozoic Origin of Animals and Their Ecosystems. Annu. Rev. Earth Pl. Sc. 33, 421-442. doi:10.1146/ annurev.earth.33.092203.122519

Noble, S. R., Condon, D. J., Carney, J. N., Wilby, P. R., Pharaoh, T. C., and Ford, T. D. (2015). U-pb Geochronology and Global Context of the Charnian Supergroup, UK: Constraints on the Age of Key Ediacaran Fossil Assemblages. Bull. Geol. Soc. Am. 127, 250-265. doi:10.1130/b31013.1

Seilacher, A. (1992). Vendobionta and Psammocorallia: Lost Constructions of Precambrian Evolution. J. Geol. Soc. Lond. 149, 607-613. doi:10.1144/ gsjgs.149.4.0607

Shen, B., Dong, L., Xiao, S., and Kowalewski, M. (2008). The Avalon Explosion: Evolution of Ediacara Morphospace. Science 319, 81-84. doi:10.1126/ science. 1150279

Steiner, M., and Reitner, J. (2001). Evidence of Organic Structures in Ediacara-type Fossils and Associated Microbial Mats. Geology 29, 1119-1122. doi:10.1130/ 0091-7613(2001)029<1119:eoosie>2.0.co;2

Tarhan, L. G., Droser, M. L., Gehling, J. G., and Dzaugis, M. P. (2015). Taphonomy and Morphology of the Ediacara Form Genus Aspidella. Precambrian Res. 257, 124-136. doi:10.1016/j.precamres.2014.11.026

Taylor, R. S., Matthews, J. J., Nicholls, R., and McIlroy, D. (2021). A Re-assessment of the Taxonomy, Palaeobiology and Taphonomy of the Rangeomorph Organism Hapsidophyllas flexibilis from the Ediacaran of Newfoundland, Canada. Pal Z., 95 (2), 187-207. doi:10.1007/s12542-020-00537-4

Vixseboxse, P. B., Kenchington, C. G., Dunn, F. S., and Mitchell, E. G. (2021). Orientations of Mistaken Point Fronds Indicate Morphology Impacted
Ability to Survive Turbulence. Front. Earth Sci. 9, 762824. doi:10.3389/ feart.2021.762824

Wade, M. (1968). Preservation of Soft-bodied Animals in Precambrian Sandstones at Ediacara, South Australia. Lethaia 1, 238-267. doi:10.1111/j.15023931.1968.tb01740.x

Waggoner, B. (2003). The Ediacaran Biotas in Space and Time. Integr. Comp. Biol. 43, 104-113. doi:10.1093/icb/43.1.104

Wang, X., Pang, K., Chen, Z., Wan, B., Xiao, S., Zhou, C., et al. (2020). The Ediacaran Frondose Fossil Arborea from the Shibantan limestone of South China. J. Paleontol. 94, 1034-1050. doi:10.1017/jpa.2020.4

Wen, B., Evans, D. A., Anderson, R. P., and McCausland, P. J. (2020). Late Ediacaran Paleogeography of Avalonia and the Cambrian Assembly of West Gondwana. Earth Planet. Sc. Lett. 552, 116591. doi:10.1016/ j.epsl.2020.116591

Wilby, P. R., Carney, J. N., and Howe, M. P. (2011). A Rich Ediacaran Assemblage from Eastern Avalonia: Evidence of Early Widespread Diversity in the Deep Ocean. Geology 39, 655-658. doi:10.1130/ g31890.1

Wood, D. A., Dalrymple, R. W., Narbonne, G. M., Gehling, J. G., and Clapham, M. E. (2003). Paleoenvironmental Analysis of the Late Neoproterozoic Mistaken Point and Trepassey Formations, southeastern Newfoundland. Can. J. Earth Sci. 40, 1375-1391. doi:10.1139/e03-048

Xiao, S., Chen, Z., Pang, K., Zhou, C., and Yuan, X. (2021). The Shibantan Lagerstätte: Insights into the Proterozoic-Phanerozoic Transition. J. Geol. Soc. Lon 178 (1), jgs2020-135. doi:10.1144/jgs2020-135

Xiao, S., and Laflamme, M. (2009). On the Eve of Animal Radiation: Phylogeny, Ecology and Evolution of the Ediacaran Biota. Trends Ecol. Evol. 24, 31-40. doi:10.1016/j.tree.2008.07.015

Xiao, S., Yuan, X., Steiner, M., and Knoll, A. H. (2002). Macroscopic Carbonaceous Compressions in a Terminal Proterozoic Shale: a Systematic Reassessment of the Miaohe Biota, South China. J. Paleontol. 76, 347-376. doi:10.1017/s0022336000041743

Conflict of Interest: The authors declare that the research was conducted in the absence of any commercial or financial relationships that could be construed as a potential conflict of interest.

Publisher's Note: All claims expressed in this article are solely those of the authors and do not necessarily represent those of their affiliated organizations, or those of the publisher, the editors and the reviewers. Any product that may be evaluated in this article, or claim that may be made by its manufacturer, is not guaranteed or endorsed by the publisher.

Copyright $\odot 2022$ Pérez-Pinedo, McKean, Taylor, Nicholls and McIlroy. This is an open-access article distributed under the terms of the Creative Commons Attribution License (CC BY). The use, distribution or reproduction in other forums is permitted, provided the original author(s) and the copyright owner(s) are credited and that the original publication in this journal is cited, in accordance with accepted academic practice. No use, distribution or reproduction is permitted which does not comply with these terms. 